\title{
Assessing the Environmental Impacts of COVID-19; A Review
}

\author{
Najabat Ali ${ }^{1 *}$, Xuhua Hu${ }^{1 * *}$, Jamal Hussain², Memoona Nilofar ${ }^{3}$ \\ ${ }^{1}$ School of Finance and Economics, Jiangsu University, 212013 Zhenjiang, China \\ ${ }^{2}$ China Western Economics Research Centre, Southwestern University of Finance and Economics, \\ 611130, Chengdu, China \\ ${ }^{3}$ Karakoram International University, Gilgit Baltistan, Pakistan
}

Received: 30 September 2020

Accepted: 10 November 2020

\begin{abstract}
The coronavirus outbreak firstly emerged from Wuhan, the economic hub of Hubei province, China, and within a short period, it appeared as a global threat. In response to the outbreak, COVID-19 has been declared as a global health emergency by the World Health Organization (WHO) on January 30, 2020. To contain the virus, the governments of the Coronavirus affected countries enforced lockdowns to ensure social distancing among the people. Additionally, people have been asked to use hand sanitizers, face masks, and gloves, etc. to prevent the effect of the disease. The lockdowns and excessive utilization of medical supplies around the globe has resulted in numerous positive and negative ecological impacts. Therefore, this study aims to review the existing literature on the environmental effects of COVID-19.
\end{abstract}

Keywords: COVID-19, global health emergency, environment, pollution

\section{Introduction}

The health authorities of China noticed a strange pneumonia case in a public hospital in Wuhan city, the economic hub of Hubei province in December, 2019. The experts linked this unknown virus with an animal selling market in Wuhan that deals in selling poultry, fish, and other wild animals [1]. In January, the Chinese authorities formally informed the World Health Organization (WHO) about this outbreak in Wuhan city of Hubei province, China, which was the epicenter of the newly emerged virus. After thoroughly looking into the matter, the World Health Organization (WHO) identified the microorganism as

*e-mail: alinajabat@hotmail.com

**e-mail: xuhuahu@163.com a newly emerged coronavirus virus and named it as COVID-19 on January 26. WHO also confirmed that recently identified Coronavirus belongs to the family of SARS and MERS [2]. The Coronavirus went through sequencing of Genome and sequencing of Genome and reverse transcription-polymerase chain reaction testing. The research and development team of WHO initiated the efforts for fast diagnoses, therapies, and vaccine development programs. As a result, a vaccine candidate was sent for initial laboratory testing [3]. On January 30, 2020, the WHO declared a global health emergency due to an increasing number of cases within and outside China [4]. The appearance of COVID-19 resulted in enormous challenges for the public health security of the world [5]. Therefore, the WHO declared COVID-19 as a global pandemic on March 11, 2020. The World Health Organization (WHO) directed governments and policymakers to take quick and aggressive actions for 
fighting against this pandemic [6]. As we are writing this study, the confirmed cases of COVID-19 have been recorded 45,921,698, while 1,193,909 have died and 33,252,218 have been recovered. The outbreak of COVID-19 has already spread in about 216 countries or territories [7].

\section{Impact of Economic Slowdown on the Environment}

The Coronavirus outbreak has hindered global public health due to the increasing number of infections and deaths in more than 200 countries around the globe. It has also excessively challenged the economic growth of the world due to ceasing economic activities globally [8]. COVID-19 has forced people to stay at homes to reduce virus transmission, which resulted in job losses and shutting down businesses. According to a report of IMF, the global economy will face a recession in 2020 by dropping growth rate at $3 \%$ due to COVID-19 [9]. The COVID-19 pandemic troubles economic development due to the increasing uncertainties of capital and financial markets [10].

Moreover, for reducing the spread of the epidemic, the governments of almost all affected countries have restricted movements of people, transportation services, and all other economic activities [11]. Various studies have forecasted that the effects of COVID-19 pandemic on economic development will outweigh the global financial crunch of 2008 [12]. Existing studies depict that economic growth is inversely proportional to pollution [8, 13]. Therefore, the lockdowns of COVID-19 have severely affected economic growth all over the world, but it has some positive effects on the natural environment [14]. For instance, the suspension of flight operations and transportation services around the globe to halt the spread of the virus has resulted in a reduction of carbon emissions [8, 15]. Additionally, the air quality in various cities has been improved due to a decline in overall economic activities. The lockdowns across the globe badly affected many sectors, including transportation. The suspension of both air and road transportation resulted in the reduction of fossil fuel consumption, and this ultimately reduces nitrogen oxide $\left(\mathrm{NO}_{2}\right)$ that is an enormous cause of traffic pollution. Traffic pollution is considered the primary source of (nitrogen oxide) $\mathrm{NO}_{2}$ emissions [16]. Nitrogen oxide is extremely harmful to human health, as many past research studies show that it can increase the mortality rate among human beings through various respiratory diseases [17]. According to estimation, 4.6 million people lost their lives annually due to polluted air. The effects of air pollution are very hazardous all over the world; for instance, 193,000 persons died in Europe in 2012 due to air pollution [18]. The reduction of transportation activities has declined energy consumption and oil demand globally [19].
The shutdown of the industrial and transportation sectors also dropped the carbon emissions, as carbon emissions in New York City have been dropped by $50 \%$ as compared to the last year due to COVD-19 measures taken by the government. According to the statistics of China, there was a $25 \%$ decline in emissions due to the cease of all economic activities. The statistics of Ecology and Environment ministry of China shows that as compared to the last year, the amount of good quality air is estimated at $11.4 \%$ in about 330 cities in China. Likewise, many other territories of Europe, such as Italy, Spain, Germany, and the UK have shown a reduction of nitrogen oxide emissions [20]. Another positive environmental aspect of COVID-2019 is that the water of Venice's canal in Italy has been seen cleaner than the past. It has become possible due to the absence of tourists in the region due to the pandemic. Moreover, the reduction of coal consumption has also contributed to drop the airborne pollutants such as $\mathrm{CO}, \mathrm{CO}_{2}$, and $\mathrm{NO}$ [21]. Although these changes have a significantly positive impact on environmental quality, but they have severely threatened the sustenance of a vast number of people. Moreover, these ecological changes are temporary due to the current lockdowns in the world. So the policymakers should find permanent ways to find the long-term solution of environmental pollution [22].

\section{Impact of Medical and Domestic Wastes on the Environment}

Due to the COVID-19 outbreak, people take precautionary measures such as using gloves, masks, and hand sanitizers, which frequently generate a massive quantity of medical trashes in the environment [19]. According to estimation, the residents of Wuhan city, the epicenter of COVID-19, generated 200 tons of medical waste in a single day on February 24. This quantity of trash is four times bigger than the capacity of a dedicated facility to incinerate the garbage daily [23]. Likewise, the USA and many other countries are also generating a massive quantity of medical trash every day. Moreover, due to the quarantine policy, many consumers choose online shopping. As a result, the domestic waste of consumers has also substantially increased [24]. The governments all over the world should find a permanent solution for waste management; otherwise, it could lead to severe problems. In the meantime, every person must follow the rules regarding discarding medical waste. Millions of people all around the world use gloves, masks, and hand sanitizers, and it has an enormous impact on the natural habitat on the land as well as seas. It could lead to severe consequences for animals, if they mistakenly eat this trash as food [6]. 


\section{Conclusion}

The study aimed to review the overall environmental impacts of the COVID-19 outbreak. The positive and negative effects of the Coronavirus outbreak have been highlighted. The economic slowdown positively affects the environment by improving the quality of air, but this change is temporary. All the countries will resume their economic activities when this pandemic ends, then once again, the hazardous emissions will hit the environment. So the policymakers should focus on significant structural changes for a long-term decline of pollutants. Moreover, waste management is essential during the days of the pandemic situation. Medical waste and domestic waste should be treated differently. All medical wastes should be disposed of separately to minimize the effects of the pandemic. Lastly, the study concludes that COVID-19 affects the environment both positively and negatively in the short-run. But in the long-run, it can negatively affect the environment, if sufficient and timely measures are not taken by the policy-makers.

\section{Conflict of Interest}

The authors declare no conflict of interest.

\section{References}

1. XU Z., SHI L., WANG Y., ZHANG J., HUANG L., ZHANG C., WANG F.S. Pathological findings of COVID-19 associated with acute respiratory distress syndrome. The Lancet Respiratory Medicine, 8 (4), 420, 2020.

2. CHEN N., ZHOU M., DONG X., QU J., GONG F., HAN Y., ZHANG L. Epidemiological and clinical characteristics of 99 cases of 2019 novel coronavirus pneumonia in Wuhan, China: a descriptive study. The Lancet, 395 (10223), 507, 2020.

3. WANG W., XU Y., GAO R., LU R., HAN K., WU G., TAN W. Detection of SARS-CoV-2 in Different Types of Clinical Specimens. JAMA - Journal of the American Medical Association, 5, 2020.

4. WHO. COVID-19 situation reports. Retrieved from http:// www.who.int/hac/crises/zwe/sitreps/epi_archive/en/ index2.html 2020.

5. SINGH MALIK Y., SIRCAR S., BHAT S., TIWARI R., SAH R., RABAAN A.A., AUTHOR C. UP Pandit Deen Dayal Upadhayay Pashu Chikitsa Vigyan Vishwavidyalay Evum Go. The Indian journal of animal sciences, March, $1,2020$.

6. HELLEWELL J., ABBOTT S., GIMMA A., BOSSE N.I., JARVIS C.I., RUSSELL T.W., EGGO R.M. Feasibility of controlling COVID-19 outbreaks by isolation of cases and contacts. The Lancet Global Health, 8 (4), e488, 2020.

7. WHO. WHO Coronavirus Disease (COVID-19) Dashboard. Who.int. Retrieved from https://covid19. who.int/?gclid=CjwKCAjwnK36BRBVEiwAsMT8W J3y00_BUzvrLsvbl3uthuoTH_Occ45gyEUbpYRyEq Azll3aZ̄B6TYxoCcM0QAvD BwE 2020.
8. WANG Q., SU M. A preliminary assessment of the impact of COVID-19 on environment - A case study of China. Science of the Total Environment, 728, 1, 2020.

9. GOPINATH G. IMF projecting $3 \%$ contraction of global GDP due to COVID-19 pandemic: Gita Gopinath - The Economic Times Video | ET Now, 2020.

10. MCKIBBIN W.J., FERNANDO R. The Global Macroeconomic Impacts of COVID-19: Seven Scenarios. SSRN Electronic Journal, March, 1, 2020.

11. DELIVORIAS A., SCHOLZ N. Economic impact of epidemics and pandemics. European Paliamentary Research Service, February, 1, 2020.

12. NICOLA M., ALSAFI Z., SOHRABI C., KERWAN A., AL-JABIR A., IOSIFIDIS C., AGHA R. The SocioEconomic Implications of the Coronavirus and COVID-19 Pandemic: A Review. International Journal of Surgery. IJS Publishing Group Ltd, 2020.

13. RAUPACH M.R., MARLAND G., CIAIS P., LE QUÉRÉ C., CANADELL J.G., KLEPPER G., FIELD C.B. Global and regional drivers of accelerating $\mathrm{CO}_{2}$ emissions. Proceedings of the National Academy of Sciences of the United States of America, 104 (24), 10288, 2007.

14. MUHAMMAD S., LONG X., SALMAN M. COVID-19 pandemic and environmental pollution: A blessing in disguise? Science of the Total Environment, 728, 1, 2020.

15. SAADAT S., RAWTANI D., MUSTANSAR, C. Science of the Total Environment Environmental perspective of COVID-19. Science of the Total Environment, 728 (1), 1, 2020.

16. HE L., ZHANG S., HU J., LI Z., ZHENG X., CAO Y., WU $Y$. On-road emission measurements of reactive nitrogen compounds from heavy-duty diesel trucks in China. Environmental Pollution, 262, 1, 2020.

17. FAUSTINI A., RAPP R., FORASTIERE F. Nitrogen dioxide and mortality: Review and meta-analysis of longterm studies. European Respiratory Journal, 44 (3), 744, 2014.

18. COHEN A.J., BRAUER M., BURNETT R., ANDERSON H.R., FROSTAD J., ESTEP K., FOROUZANFAR M.H. Estimates and 25-year trends of the global burden of disease attributable to ambient air pollution: an analysis of data from the Global Burden of Diseases Study 2015. The Lancet, 389 (10082), 1907, 2017.

19. SAADAT S., RAWTANI D., HUSSAIN C.M. Environmental perspective of COVID-19. Science of the Total Environment, 728, 138870, 2020.

20. STONE M. Carbon emissions are falling sharply due to coronavirus. But not for long, n.d.

21. LAU H., KHOSRAWIPOUR V., KOCBACH P., MIKOLAJCZYK A., SCHUBERT J., BANIA J., KHOSRAWIPOUR T. The positive impact of lockdown in Wuhan on containing the COVID-19 outbreak in China. Journal of travel medicine, 001 (714), 1, 2020.

22. MCCLOSKEY B., HEYMANN D.L. SARS to novel coronavirus - Old lessons and new lessons. Epidemiology and Infection, May, 1, 2020.

23. LUAN P.T., TAK-SHING CHING C. A Reusable Mask for Coronavirus Disease 2019 (COVID-19). Archives of Medical Research, 2019, 1, 2020.

24. CALMA J. The COVID-19 pandemic is generating tons of medical waste Sanitation workers need personal protective equipment too. The Verge. Retrieved from https://www. theverge.com/2020/3/26/21194647/the-covid-19-pandemicis-generating-tons-of-medical-waste 2020. 
